\title{
Selected aspects of Lycopodium annotinum L. sporulation
}

\author{
Anna Śliwińska-Wyrzychowska, Monika Bogdanowicz \\ Department of Botany and Plant Ecology, Institute of Chemistry, Environmental Protection and Biotechnology, \\ Jan Długosz University, Al. Armii Krajowej 13/15, 42-201 Częstochowa, Poland, \\ e-mail: m.bogdanowicz@gmail.com
}

\begin{abstract}
The conducted study aimed to show the differences in the process of sporulation at two populations of Lycopodium annotinum L. occurring within the governmental forests in the habitats: undisturbed and disturbed by economic treatments. The study was conducted in 2008-2011 in the southern part of the Krakowsko-Częstochowska Upland. It concerned the number of observations of sporophylls occurring during the year. There was also examined till which months within the year spores are released. The study also included observations of the lot of sporophylls which released the spores. Studies have shown that in the undisturbed habitat during the year there occurred 6 times more sporophylls than in the disturbed habitat. It was also observed that the period of their appearance in the undisturbed habitat was prolonged compared to literature data, and lasted until November 2008. Such a late appearance of sporophylls was not in the disturbed habitat, where the appearance of sporophylls was observed only until July 2008. However, only in the disturbed habitat there was observed occurrence of sporophylls in March 2009. In the undisturbed habitat spore release process lasted until October 2008, while in the disturbed one until September. In this habitat there was also observed that $28 \%$ of marked shoots with strobili died before the release of spores. This situation was not observed in the undisturbed habitat. The study also showed that in the both positions, after releasing the spores, all the shoots died within 3 years, however, in the disturbed habitat shoots died much faster than in the undisturbed one.
\end{abstract}

Key words: strobili, undisturbed habitat, disturbed habitat, insolation.

\section{Introduction}

Lycopodium annotinum $\mathrm{L}$. is under strict species protection (The Minister of Environment 2004). It occurs mostly in shady places, usually in coniferous forest habitats. This species occupies space in two ways: by vegetative reproduction and by the production of spores (Piękoś-Mirkowa $\&$ Mirek 2003). Vegetative occupying of the space is done along with sprawling of the policormon so it refers to a small space. At much greater distances club moss spreads through spores. However, their life small and amounts to only $4 \%$ at the number of spores of up to 1.88 million at $0.01 \mathrm{~m}^{2}$ (Callaghan et al. 1986b). In addition, the period which elapses from the moment of spore settle on favorable habitat to the appearance of sporophyte, may take several or even more than a dozen years. (Grochowski 1956; Podbielkowski et al. 1986; Piękoś-Mirkowa \& Mirek
2003). Certainly such a long development cycle of Lycopodium annotinum $\mathrm{L}$. does not favour its competitiveness in dealing with space for other species. In addition, the reproduction of existing populations may be hindered or prevented by their damage or total destruction. The immediate cause of the destruction of the existing population is illegal harvesting of club moss shoots by humans, mainly for ornamental purposes (Piękoś-Mirkowa \& Mirek 2003). It comes to the destruction of a part or even a whole policormon as a result of its uprooting. Another threat to Lycopodium annotinum $\mathrm{L}$. are the economic treatments and complete fellings conducted in the governmental forests.

The gametophyte and sporophyte of club mosses due to differences in its structure and the different conditions under which it may grow, require very different research approaches. In Europe, the most popular were researches referring to club moss sporophytes. In European studies of 
club mosses, we usually meet analyses of the ways club moss shoots colonize the space as well as analyses of nutritional management of compounds within policormon (Callaghan et al.1986a, b; Callaghan et al. 1986b; Svensson \& Callaghan 1988a; Callaghan et al. 1990). On the territory of Poland there were conducted mainly studies of the club moss spatial structure and conservation status and condition of the existing populations (Juchacz et al. 1993; Rudak 2001; Bogdanowicz \& Śliwińska-Wyrzychowska 2008; Sonneberger et al. 2008a, b; Śliwińska-Wyrzychowska \& Bogdanowicz 2008). Issues connected with maintaining a good condition of the population appeared in many studies (Hornbeck et al. 2003; Bruce et al. 2004; Gilman \& Vermont. 2004) but it concerned club mosses occurring on the area of the USA. Until now, however, there has not been conducted a research associated with sporulation of club mosses in the habitats disturbed by the carried out treatments related to forest management.

From the literature data concerning the care of the forest it results that the complete fellings with plowing used after them, prevent the survival of plants occurring in the area.

Also in the case of lighter treatments (thinning, cleaning) there may lead to the disappearance of some more vulnerable plant species due to changes in the microclimate of the forest communities (changes in humidity, insolation and temperature) (Gorzelak 2009). Gorzelak (2009) in his study provides information on Diphasiastrum complanatum (L.) Holub occurring in a part of the forest where there was carried out a thinning. The author, however, did not perform tests on the condition, nor sporulation of the observed population, putting an emphasis on the general issues connected with the protection of club moss stands on the forest areas undergoing economic development.

The aim of the study was to determine whether there are differences in the process of sporulation of Lycopodium annotinum L. shoots in the population located on the habitat disturbed by the economic treatments compared to the population in undisturbed habitat. There was examined whether the two populations (with similar dimensions) produce a similar number of sporophylls during the year. There was also examined the latest month till which the sporophylls appear in each of the studied populations and whether the strobili on the two stands appear in the same months. There was also tested when spores are released from the formed sporophylls and whether all the shoots that developed a sporophyll, sporulate. There was also observed how quickly after spore spilling a sporophyll dies and what happens further with the vertical sporophyll after releasing the spores.

\section{Methodology}

The study area included the areas of Złoty Potok Forestry located in Krakowsko-Częstochowska Upland in the south- ern part of Poland. The study was conducted in 2008-2011. It is assumed that each shoot creeping over the surface of the soil will be called a horizontal shoot, while single branches growing from it are vertical shoots. Two populations of Lycopodium annotinum L. located in mixed forests on moist habitats were chosen for the study (Forest management plan from 2006 to 2015). The first population occurred in the undisturbed habitat (Dziadówki) but the other one in the disturbed habitat (Julianka). Habitat disturbance was associated with economic treatments carried out in the state forest. At the disturbed habitat, there was carried out a complete felling on the forest part adjacent to the club moss population. This led to the unveiling of the eastern side of the greater part of the population, exposing it to increased insolation. The remaining part was under the canopy of treetops and undergrowth.

In Poland, the period of spore maturation starts in July (Kremer \& Muhle 1998; Rutkowski 2007; Wójciak 2007). The study started in July, assuming that if the data given in the literature is accurate, then this month all strobili starting from the should be already developed. To observe the appearance of soprophylls there were set 6 squares with dimensions $1 \times 1 \mathrm{~m}$ on each of the stands. The squares were established in places of the greatest condensation of vegetative shoots (visual estimation). In each of them from July to December 2008 there were counted newly appearing sporophylls. In order to distinguish strobil generated in the coming months, they marked in different colored threads. In March 2009, at the time of checking the condition of the population after the trees were felled by snow in winter, there were re-counted the newly formed sporophylls. In order to check whether there is a difference in the number of strobili formed at the both stands during the year, there was conducted another count in August 2009. In the studies there was also assumed that after determining to which month the sporophylls appear, a year later, analogical observations will be carried out to investigate the repeatability of the phenomenon.

In order to study the spilling time of spores from shoots which till July 2008, developed a sporophyll, there were selected 60 shoots at each stand - a total of 120 shoots with strobili. They were all marked with numbered badges. From July to December 2008 in each month there were counted the strobili which started sporulation. In the case of strobili that could occur in the autumn months there was made the assumption that they will be marked in other way to check when the spores are released from them. From 2009 to 2011 in the summer months, there were conducted observations of the state of shoots with sporophylls, from which spores were released. In 2008 for the study there were randomly selected 60 sporophylls on each of the stands (total of 120 shoots). Each sporophyll was marked by tying a badge with a number to it. Within 3 years of research, not all the marked shoots were found. The reason 
for this is the natural growth of the species of fleece and a moss layer, which "cover" some club moss shoots. To avoid the damage to the policormon structure the litter was not dug up in search of the marked shoots. Of all the selected shoots, over 3 years there were systematically found: 53 vertical shoots in the disturbed habitat (Julianka) and 46 shoots in the undisturbed stand (Dziadówki).

\section{Results}

\subsection{Sporophyll occurrence}

The conducted studies show that within the studied squares on the disturbed stand in Julianka, from 2008 to August 2009 there were a total of 282 sporophylls (Table 1). In the same period in the squares of the undisturbed stand in Dziadówki there were 1816 of them, which is 6 times more than on the disturbed stand (Table 2).

There were also observed differences in the time of sporophyll appearance. In 2008 in the population in Julian$\mathrm{ka}$, sporophylls were formed until July. In the following months of that year, the appearance of new strobili was not observed. In the population in Dziadówki sporophylls appeared till November. The largest number was formed till July 2008 (702 ears) (Table 2). In other months the number of new strobili was much lower and amounted to a maximum of 53 ears per month (Table 2). It was also observed that in October and November there was a slight increase in the number of strobili occurring in relation to the month of September, where there were the least (19 ears) during the observed months. There was not noticed the

Table 1. The dynamics of sporophyll occurrence in the disturbed habitat in Julianka

\begin{tabular}{|c|c|c|c|c|c|c|c|c|c|}
\hline Julianka & \multirow{3}{*}{$\begin{array}{c}\text { The } \\
\text { number of } \\
\text { strobili }\end{array}$} & \multirow{2}{*}{\multicolumn{7}{|c|}{ The number of new strobili }} & \multirow{9}{*}{$\begin{array}{l}\text { The total } \\
\text { number of } \\
\text { strobili }\end{array}$} \\
\hline \multirow{2}{*}{$\begin{array}{l}\text { The number of } \\
\text { a study plot/ } \\
\text { month, year }\end{array}$} & & & & & & & & & \\
\hline & & VIII 2008 & IX 2008 & X 2008 & XI 2008 & XII 2008 & III 2009 & VIII 2009 & \\
\hline 1 & 17 & 0 & 0 & 0 & 0 & 0 & 1 & 15 & \\
\hline 2 & 15 & 0 & 0 & 0 & 0 & 0 & 3 & 28 & \\
\hline 3 & 22 & 0 & 0 & 0 & 0 & 0 & 0 & 31 & \\
\hline 4 & 22 & 0 & 0 & 0 & 0 & 0 & 0 & 42 & \\
\hline 5 & 18 & 0 & 0 & 0 & 0 & 0 & 0 & 34 & \\
\hline 6 & 19 & 0 & 0 & 0 & 0 & 0 & 0 & 15 & \\
\hline Sum & 113 & 0 & 0 & 0 & 0 & 0 & 4 & 165 & 282 \\
\hline
\end{tabular}

Table 2. The dynamics of sporophyll occurrence in the disturbed habitat in Dziadówki

\begin{tabular}{|c|c|c|c|c|c|c|c|c|c|}
\hline Dziadówki & \multirow{2}{*}{$\begin{array}{l}\begin{array}{c}\text { The number } \\
\text { of strobili }\end{array} \\
\text { do VII } 2008\end{array}$} & \multicolumn{7}{|c|}{ The number of new strobili } & \multirow{8}{*}{$\begin{array}{l}\text { The total } \\
\text { number of } \\
\text { strobili }\end{array}$} \\
\hline $\begin{array}{c}\text { The number of } \\
\text { a study plot/ } \\
\text { month, year }\end{array}$ & & VIII 2008 & IX 2008 & X 2008 & XI 2008 & XII 2008 & III 2009 & VIII 2009 & \\
\hline 1 & 41 & 8 & 2 & 0 & 0 & 0 & 0 & 146 & \\
\hline 2 & 98 & 11 & 11 & 0 & 6 & 0 & 0 & 169 & \\
\hline 3 & 28 & 4 & 1 & 0 & 0 & 0 & 0 & 80 & \\
\hline 4 & 150 & 17 & 1 & 19 & 10 & 0 & 0 & 173 & \\
\hline 5 & 190 & 6 & 1 & 17 & 13 & 0 & 0 & 138 & \\
\hline 6 & 195 & 7 & 3 & 15 & 10 & 0 & 0 & 246 & \\
\hline Sum & 702 & 53 & 19 & 51 & 39 & 0 & 0 & 952 & 1816 \\
\hline
\end{tabular}


Table 3. The dynamics of spore releasing from the observed shoots in the disturbed habitat in Julianka and in the undisturbed one in Dziadówki

\begin{tabular}{|c|c|c|c|c|c|c|c|c|c|}
\hline \multirow{2}{*}{\multicolumn{2}{|c|}{$\frac{\text { Location }}{\text { Shoots/Year }}$}} & \multicolumn{4}{|c|}{ Julianka } & \multicolumn{4}{|c|}{ Dziadówki } \\
\hline & & VII 2008 & VIII 2008 & IX 2008 & X 2008 & VII 2008 & VIII 2008 & IX 2008 & X 2008 \\
\hline \multicolumn{2}{|c|}{ the withered strobili [\%] } & 0 & 0 & 0 & 28 & 0 & 0 & 0 & 0 \\
\hline \multirow{2}{*}{$\begin{array}{l}\text { the spilled } \\
\text { strobili }\end{array}$} & total [\%] & 0 & 53 & 72 & 72 & 0 & 43 & 87 & 100 \\
\hline & $\begin{array}{l}\text { from the recent } \\
\text { month }[\%]\end{array}$ & 0 & 53 & 18 & 0 & 0 & 43 & 42 & 13 \\
\hline \multicolumn{2}{|c|}{ the unspilled strobili [\%] } & 100 & 47 & 28 & 0 & 100 & 57 & 13 & 0 \\
\hline
\end{tabular}

Table 4. The death rate of shoots after releasing spores from strobili

\begin{tabular}{|c|c|c|c|c|c|c|c|c|c|}
\hline \multirow{2}{*}{\multicolumn{2}{|c|}{$\begin{array}{l}\text { Location } \\
\text { Shoots/Year }\end{array}$}} & \multicolumn{4}{|c|}{ Julianka } & \multicolumn{4}{|c|}{ Dziadówki } \\
\hline & & 2008 & 2009 & 2010 & 2011 & 2008 & 2009 & 2010 & 2011 \\
\hline \multicolumn{2}{|c|}{ the live shoots [\%] } & 100 & 36 & 2 & 0 & 100 & 91 & 37 & 0 \\
\hline \multirow{2}{*}{$\begin{array}{l}\text { the dead } \\
\text { shoots [\%] }\end{array}$} & total $[\%]$ & 0 & 64 & 98 & 100 & 0 & 9 & 63 & 100 \\
\hline & $\begin{array}{l}\text { from the recent } \\
\text { year }[\%]\end{array}$ & 0 & 64 & 34 & 2 & 0 & 9 & 54 & 37 \\
\hline
\end{tabular}

occurrence of new strobili in December 2008 (Table 2). In March 2009, during the observations of the posts there was reported that within the squares in the disturbed habitat there were 4 new soprophylls (Table 1). Within the research squares on the undisturbed stand in Dziadówki, new sporophylls were not observed in the same month. On the same stand in August 2009 there was observed strobil sporulation which were formed in October 2008.

\subsection{Spores releasing}

The conducted study showed differences in the time of spore spilling from sporophylls in the population of the disturbed habitat in relation to the population in the undisturbed habitat. In the undisturbed habitat all sporophylls, marked in July 2008, released spores by the end of October of the same year. Percentage, the largest number of spores was released in August 2008 (57\% of all marked shoots). The smallest number of spores was released from the strobili in October 2008 (13\%) (Table 3). All marked shoots released spores, and there was noticed no shoot or strobil die before their release. On the disturbed stand, as in the case of the undisturbed one, most spores were released in August (53\%) (Table 3). However, the last release of spores on the marked shoots took place in September 2008 and not in October as it was in the undisturbed habitat. In October, however, there was reported that $28 \%$ of the observed sporophylls that did not release spores in September and August 2008, died along with the shoot not releasing spores (Table 3). This phenomenon was not observed in the undisturbed habitat where spores were released from all observed strobili (100\%).

\subsection{The lot of shoots}

The conducted observations showed that on the both stands in Dziadówki and Julianka, all shoots after spilling the spores from the strobili in 2008, died within 3 years (Table 4). On the stand in Dziadówki the smallest number of shoots, because only $9 \%$, died in the first year after the spore spilling - 2009. While most - 54\%, died in $2010-$ the second year after the release of spores. In 2011 on the stand in Dziadówki all the observed shoots were already dead. On the stand in Julianka till 2011 also all the shoots, which in 2008 released spores, died. In contrast to the population located in the undisturbed habitat in Julianka most shoots - as much as $64 \%$, died in the first year after spore releasing. In 2010 there were only $2 \%$ of live shoots that died one year later (Table 4).

\section{Discussion}

During the treatments in the forests, while storing or dragging tree boughs across the fleece surface, it may come to the violation of the policormon structure by the damage of its parts. In the case of complete fellings in the result of conducted treatments it often comes to the destruction 
of the entire club moss population and its habitat. Even if a part of the population were preserved, a drastic change in microclimatic conditions would prevent its further existence (Gorzelak 2009). In order to protect populations of rare species, on the felling areas there are left so called ecological clumps the surface of which may amount to $5 \%$ of the handling surface of the felling. These are fragments of trees located directly over the populations of protected species. Trees and shrubs forming such a clump protect the undergrowth from direct sunlight (full illumination). Despite this, there is a strong change of club moss living conditions, which contributes to a significant reduction in viability of the entire population (Śliwińska-Wyrzychowska $\&$ Bogdanowicz unpublished data). A similar disturbances of microclimate may also occur when the population is located in the immediate vicinity of the conducted felling. Although the soil microhabitat is not then destroyed, the direct exposure of its parts to the full sun brings about a change that of microclimatic conditions of this part, thus affecting the living conditions of plants growing there, including club mosses.

In the literature there are no studies on the effects of such treatments on the phenomenon of sporulation of club mosses population. However, it seems obvious that the increased insolation caused by the felling conducted in the immediate vicinity of club moss populations (as it was the case in this study), should somehow influence the reproduction, condition and survival rate of this shade tolerant species.

Planning a study concerning the date of the sporophyll occurrence and releasing spores from them was based on literature data. There is stated that the spores of Lycopodium annotinum L. "ripen from July to September" (Kremer \& Muhle 1998; Wójciak 2007; Piękoś-Mirkowa \& Mirek 2003). We made an assumption that it is a time limit within which the spores reach maturity and are released from the sporangia. The results of our studies have shown, however, that sorophylls also appear in other months, namely in October and November, which is longer than it would follow from the literature. This implies a postponement of the term in which the strobil maturation and spore release take place, for the months of late autumn (November) and even March next year. This phenomenon was observed only on the stand undisturbed by economic treatments. As the carried out study shows, it was not a one-time situation, since it repeated the following year. This means that in 2008 and 2009, there was observed the occurrence of new strobili exactly in the same months. The undeniable fact is that most sporophylls appeared in the summer - as the literature provides. During the conducted studies it was observed that some of strobili formed in autumn of 2008 , sporulated only in August 2009. This could be due to the slowdown in the growth of strobili (and thus the maturation of spores) in the autumn and winter months of 2008 and 2009, due to low temperatures. It is possible that the process of further growth and maturation began again with the increase of temperature in the spring of 2009, however, this claim remains in the zone of conjecture. Studies on the club moss sporulation were led by only a few authors (Sonnberger 1995; Sonnberger et al. 2008a, b). Sonnberger (1995) conducted several - year observations of a number of sporophylls of several Lycopodium. annotinum L. populations near Memmingen in Germany. These strobili matured in the winter months, including December. The author has identified in several populations the two phases of regular sporulation excluding the dependence of this phenomenon on weather conditions. In addition to the normal period of sporulation he observed the other one from February to March. Sonnberger (Sonnberger et al. 2008a, b) confirmed this phenomenon again in Germany and on Krakowsko-Częstochowska Upland observing spore release in the winter. In the present study there was observed no formation of strobili or their sporulation in the winter months. Basing on these studies and research of Sonnberger (1995, 2008a, b), however, one can assume that the strobili of Lycopodium annotinum L. in favorable conditions can mature and sporulate not only in the period given by the literature. The phenomenon of multiple sporulation was also observed by other researchers and it refered to the species of Matteuccia struthiopteris (L.) Tod. and Equisetum subgen. Hippochaete (J. Milde) Baker (Horn after Sonnberger, unpublished data). Sporulation in winter was also observed at Equisetum telmateia Ehrh. (Peters \& Bennerth 1987). The authors of these observations, however, drew attention to the irregularity of the phenomenon resulting from weather conditions which Sonnberger (1995) ruled out as the ones having an impact on winter sporulation at Lycopodium annotinum L. There can be drawn conclusions that the sporulation of Lycopodium annotinum L. in undisturbed conditions lasts much longer than the literature provides. On the basis of the conducted studies it is not possible to answer the question whether the four sporophylls, which appeared in March 2008 are the result of the tendency of Lycopodium annotinum L. to multiple sporulation or whether the sporophylls are the result of disturbances and earlier start of strobil production by the population as a result of changes in microhabitat conditions.

Also, significantly fewer sporophylls observed by us in the disturbed habitat may be caused by the change in microclimatic conditions, and largely by increased insolation. Lycopodium annotinum L. is a circum-boreal species which requires moderately shaded places for the proper development (Zarzycki et al. 2002; Piękoś-Mirkowa \& Mirek 2003). Already MacArthur and Connell (1971) stated that the response of plants to environmental conditions may be manifested in their reproductive abilities. Disorder of the microhabitat of the studied population could therefore lead 
to reduced production of soprophylls. As the club moss shoots subjected to increased exposure light tend to dying (Śliwińska-Wyrzychowska \& Bogdanowicz unpublished data), perhaps as a consequence it can stop the process of strobili production, which seems to be in these conditions, too much effort for the plant. Parts of fleece, which began to reach a large amount of sunlight, stop being a convenient place to live for Lycopodium annotinum L. because it prefers moist habitats and such are usually formed in the more shaded areas. In the case of unfavorable microhabitats Lycopodium annotinum L. uses so called opportunistic escape or "tactics of a seeker" (Callaghan et al. 1986a; Svensson \& Callaghan 1988a, b). Opportunistic escape is to avoid adverse microhabitats, and the tactics of a seeker is to look for the ones in which a ramet will be placed on a suitable location for further development. It can be assumed that in the disturbed habitat Lycopodium annotinum L. redirected some resources meant reproductive effort, for vegetative occupation of space or being in a stressful situation it reduced energy consumption for reproduction. However, to confirm this hypothesis it would necessary to conduct the studies on the energy economy of club moss population in the both habitats.

The process of strobil drying along with a shoot before spore releasing observed on the stand in Julianka, also may be associated with increased insolation. The fact that this phenomenon was not observed in the undisturbed habitat also supports this thesis. Probably these shoots, as a result of increased insolation, began to wither away and so did the sporophylls in which spores did not manage to mature. The study also showed that all the shoots that developed a sporophyll, die within 3 years from the spore release. This situation occurred in the both habitats disturbed and undisturbed one. According to a Callaghan and others study (Callaghan et al. 1986b) vertical shoots after releasing the spores are still alive for eight years before it comes to their total decay. This author observed, however, populations located in areas of Swedish Lapland in the Boreal zone. This area is characterized by a much shorter growing season and harsher winters than climate of Poland (Podbielkowski 1975; Kornaś \& Medwecka-Kornaś 1986). Just this difference in climatic conditions may result in a shorter period of dieback of shoots on the stands observed by us. Within the studied stands differences in the number of strobili dying in the first year after the spore releasing can be attributed to the change of microclimatic conditions, and above all, the increased sun exposure which the population in the disturbed habitat was subjected to. This disorder can have a direct impact on the change of biogeochemical cycle of nitrogen. Any disturbances in the habitat connected with the change of the stand density lead to its loss from the soil (Smith et al. 1986). This is not a desirable phenomenon, since nitrogen is responsible for the production of a well functioning photosynthetic appa- ratus (Stremińska \& Błaszczyk 2004). The modular nature of the construction of Lycopodium annotinum L. makes it possible to transport water and nutrients between the individual shoots within the clone (Headley et al. 1988a). In addition, these compounds from dying shoots are recovered and then transported to the younger segments. In the present study on the disturbed stand the greater number of shoots dying in the first year after releasing the spores may be associated not only with microclimatic changes but also with the disruption of the nitrogen availability in the soil. It is also possible that the faster decay of shoots directly subjected to strong insolation, has a beneficial effect on the rest of the population. This is because it has no need to "maintain" exposed shoots, regaining from some of them, nutrients needed for younger parts of the clone to survive.

\section{References}

Bogdanowicz M. \& Śliwińska-Wyrzychowska A., 2008, The spatial structure and condition of Lycopodium clavatum L. in Zrębice Forestry, [in:] E. Szczęśniak (ed.), Endangered, expansive and invasive species in pteridoflora of Lower Silesia. Club-mosses, horsetails and ferns in Poland - resources and protection, Polish Botanical Society, Institute of Plant Biology, University of Wrocław, Wrocław: 255-263.

Bruce J. G, Wagner W. H. \& Beitel J. M., 2004, Conservation assessment for Northern Appressed Club - moss (Lycopodiella subappressa and Nothern Prostrate Clubmoss (Lycopodiella margueritae), USDA Forest Service, Eastern Region.

Callaghan T. V., Headley A. D., Svensson B. M, Lixian L., Lee J. \& Lindley D. K., 1986a, Modular growth and function in the vascular cryptogam Lycopodium annotinum, Proceedings of the Royal Society of London 228: 195-206.

Callaghan T. V, Svensson B. M., Bowman H., Lindley D. K. \& Carlsson B. A., 1990, Models of clonal plant growth based on population dynamics and architecture, Oikos 57: 257-269.

Callaghan T. V., Svensson B. M. \& Headley A., 1986b, The modular growth of Lycopodium annotinum, Fern Gazette, Journal of the British Pteridological Society 13: $65-76$.

Gilman A. G. \& Vermont M., 2004, Lycopodiella alopecuroides (L.) Cranfill Foxtail bog-clubmoss. New England Plant, Conservation Program Conservation and Research Plan for New England, New England Wild Flower Society.

Gorzelak P., 2009, Nowe stanowisko widlicza spłaszczonego Diphasiastrum complanatum L. (Lycopodiaceae) na Dolnym Śląsku i możliwości jego ochrony z punktu widzenia leśnika [The new stand of Diphasiastrum 
complanatum L. (Lycopodiaceae) in Lower Silesia and the possibilities of its protection from the standpoint of the forester], Acta Botanica Silesiaca 4: 125-133.

Grochowski W., 1956, Chrońmy widłaki [Let's protect Lycopods], Państwowa Rada Ochrony Przyrody PWN, Warszawa.

Headley A. D. Callaghan T. V. \& Lee J. A., 1988a, Phosphate and nitrate movement in the clonal plants Lycopodium annotinum L. and Diphasiastrum complanatum (L.) Holub, New Phytologist 110: 487-495.

Headley A. D., Callaghan T. V. \& Lee J. A., 1988b, Water uptake and movement in the clonal plants, Lycopodium annotinum L. and Diphasiastrum complanatum (L.) Holub, New Phytologist 110: 497-502.

Hornbeck J. H., Reyher D. J., Sieg C. \& Crook R. W., 2003, Conservation assessment for groundcedar and stiff clubmoss in the Black Hills National Forest South Dakota and Wyoming. United States Department of Agriculture, Forest Service, Rocky Mountain Region, Black Hills National Forest Custer, South Dakota.

Juchacz A., Lembicz M. \& Zątek W., 1993, Stan populacji L. clavatum i L. annotinum w Wielkopolskim Parku Narodowym w latach 1992-1993 [The population of L. clavatum and L. annotinum in Wielkopolski National Park in 1992-1993], Prace i materiały muzeum im. Prof. W. Szafera: 71-76.

Kornaś J. \& Medwecka-Kornaś A., 1986, Geografia roślin [Geography of Plants], PWN, Warszawa.

Kremer B. P. \& Muhle H., 1998, Leksykon przyrodniczy: porosty, mchy, paprotniki [Nature lexicon: Lichens, Bryophytes and Pteridophytes], GeoCenter, Warszawa.

MacArthur R. H. \& Connell J. H., 1971, Biologia populacji [Population biology], Państwowe Wydawnictwo Rolnicze i Leśne, Warszawa.

Peters U. \& Bennerth H. W., 1987, Beobachtungen zur Ausbildung sporenerzeugender Triebe bei Equisetum telmateia, Decheniana 140: 36-40.

Piękoś-Mirkowa H. \& Mirek Z., 2003, Flora Polski. Atlas Roślin Chronionych [Polish flora. Atlas of Polish protected plants], MULTICO Oficyna Wydawnicza, Warszawa.

Podbielkowski Z., 1975, Roślinność kuli ziemskiej [Vegetation of the Earth], Wydawnictwa Szkolne i Pedagogiczne, Warszawa.

Podbielkowski Z., Rejment-Grochowska I. \& Skrigiełło A., 1986, Rośliny zarodnikowe [Spore-bearing plants], Wyd. 4, PWN, Warszawa.

Regionalna Dyrekcja Lasów Państwowych w Katowicach, „Plan urządzenia lasu na okres od 1 stycznia 2006 r. do 31 grudnia 2015 r. na podstawie stanu lasu w dniu 1 stycznia 2006 r.”, tom I, Ogólny opis lasów nadleśnictwa, „Nadleśnictwo Złoty Potok, Obręby: Olsztyn i Złoty Potok" Biuro Urządzania Lasu i Geodezji Leśnej, Oddział w Krakowie, [Regional Directorate of
State Forests in Katowice, ,The forest management plan for the period from 1 January 2006" to 31 December 2015 based on the state forest on 1 January 2006", Volume I, General description of forests of the Forest District, ,Złoty Potok Forest District, Grounds: Olsztyn and Złoty Potok" Bureau of Forestry and Forest Geodesy, Department in Cracow, ].

Rozporządzenie Ministra Środowiska z dnia 9 lipca 2004 r. w sprawie gatunków dziko występujących roślin objętych ochroną, Dz. U. z dnia 28 lipca 2004 roku Nr 168, poz. 1764 [The Minister of Environment, Regulation on 9 July 2004 on the species of the wild existing plants being under protection, Journal of Laws of 28 July 2004 No. 168, 1764].

Rudak M., 2001, Badania populacji Diphasiastrum complanatum (L.) Holub. na terenie Sulejowskiego Parku Krajobrazowego [The study of Diphasiastrum complanatum (L.) Holub population in Sulejowski Landscape Park], [in:] J. K. Kurowski, P. Witosławski (eds.), Funkcjonowanie Parków Krajobrazowych [Functioning of Landscape Parks], Wydawnictwa Uniwersytetu Łódzkiego, Łódź: 127-129.

Rutkowski L., 2007, Klucz do oznaczania roślin naczyniowych Polski niżowej [Identification Key for Vascular Plants of Lowland Poland], Wydawnictwo. Naukowe PWN, Warszawa.

Smith W., Borman F. H. \& Likens G. E., 1986, Response of chemoautotrophic nitrifierss to forest cutting, Soil Science 106: 471-473.

Sonnberger B., Śliwińska-Wyrzychowska A. \& Bogdanowicz M., 2008a, Sporulation of Lycopodium annotinum L. in winter, Botanical Society of the British Isles 109: 27-28.

Sonnberger B., Śliwińska-Wyrzychowska A. \& Bogdanowicz M., 2008b, Wintersporen bei Lycopodium annotinum L. in ganz Europa? Berichte der Bayerischen Botanischen Gesellschaft 78: 49-52.

Sonnberger von B.,1995, Doppelte Sporenreife bei Lycopodium annotinum L., Berichte der Bayerischen Botanischen Gesellschaft 65: 93-94.

Stremińska M. A. \& Błaszczyk M., 2004, Cykl biogeochemiczny azotu w glebach ekosystemów borów iglastych [Biogeochemical cycle of nitrogen in soils of coniferous forests ecosystems], Polskie Towarzystwo Mikrobiologów, Postępy Mikrobiologii 43: 235-250.

Svensson B. M. \& Callaghan T. V., 1988a, Small-scale vegetation pattern related to the growth of Lycopodium annotinum and variations in its micro-environment, Vegetatio 76: 167-177.

Svensson B. M. \& Callaghan T. V., 1988b, Apical dominance and the simulation of metapopulation dynamics in Lycopodiun annotinum, Oikos 51: 331-342.

Śliwińska-Wyrzychowska A., 2008a, The condition of selected Lycopodium annotinum cenopopulations at the 
Olkusz Upland (Southern Poland), [in:] P. Kočárek, V. Plášek, K. Malachová, S. Cimalová (eds.), 2008, Environmental changes and biological assessment, IV Scripta Facultatis Rerum Naturalium Universitatis Ostraviensis, No 186, Ostrava: 309-314.

Śliwińska-Wyrzychowska A., 2008b, The structure of selected stands of Lycopodium annotinum L. on the grounds of the Opoczno Forestry Management, [in:] E. Szczęśniak (ed.), Club-mosses, horsetails and ferns in Poland - resources and protection. Polish Botanical Society \& Institute of Plant Biology, University of Wrocław, Wrocław: 235-244.

Śliwińska-Wyrzychowska A. \& Bogdanowicz M., 2008, The spatial structure and condition of Lycopodium annotinum populations in the "Sokole Góry" Reserve and managed forest in Zrębice Forest Division (Czestochowa Upland, Southern Poland), [in]: P. Kočárek, V. Plášek, K. Malachová, S. Cimalová (eds.), Environmental changes and biological assessment, IV Scripta Facultatis Rerum Naturalium Universitatis Ostraviensis, No 186, Ostrava: 315-320.

Wójciak H., 2007, Porosty, mszaki, paprotniki [Lichens, Bryophytes and Pteridophytes], Multico Oficyna Wydawnicza, Warszawa.

Zarzycki K., Trzcińska-Tacik H., Różański W., Szeląg Z., Wołek J. \& Korzeniak U., 2002, Ekologiczne liczby wskaźnikowe roślin naczyniowych Polski [Ecological indicator values of vascular plants of Poland], Instytut Botaniki PAN, Kraków. 